SHORT REPORT

\title{
Prenatal exposure to arecoline (areca nut alkaloid) and birth outcomes
}

\author{
O García-Algar, O Vall, F Alameda, C Puig, M Pellegrini, R Pacifici, S Pichini
}

Arch Dis Child Fetal Neonatal Ed 2005;90:F276-F277. doi: 10.1136/adc.2004.061325

The betel nut is commonly used as a drug by Asian populations. A high prevalence of adverse pregnancy outcomes has been reported in women who chewed betel quid during gestation. The hypothesis that chronic exposure of the fetus to arecoline (the principal alkaloid of the areca nut) is the cause was investigated in a clinical observational study on six newborns from Asian mothers who chewed betel nut during pregnancy.

$\mathrm{T}$ he betel nut, composed of the sliced nut of the areca palm (areca nut), the leaf of the betel pepper (Piper betle), and

lime, is a drug commonly consumed by Asian populations and Asian communities living in Europe and North America. ${ }^{1}$

Some authors have reported a significantly higher prevalence of adverse pregnancy outcomes, including spontaneous abortion, low birth weight, and preterm birth, ${ }^{2}$ among women who chewed betel quid during gestation than in nonconsumers. However, none hypothesised chronic exposure of the fetus to arecoline (the principal alkaloid of the areca nut) as a possible mechanism.

To investigate if chronic exposure to arecoline can lead to adverse birth outcomes, some not yet recognised, we set up a clinical observational study on six newborns from Asian mothers who admitted to betel nut consumption during pregnancy.

Pregnant women, recruited within the framework of the Meconium Project at the Hospital del Mar in Barcelona Spain, had a complete clinical examination and were interviewed about their use of cigarettes and illicit drugs during pregnancy. At the time of delivery, newborn somatometry and clinical signs were recorded.
Arecoline concentration was determined in meconium to assess fetal exposure to this alkaloid and in the placenta, to be associated with studies on the morphology of placental tissue from consumer mothers. ${ }^{3}$ Meconium samples were also analysed for the principal drugs of abuse and cotinine to exclude prenatal exposure to drugs other than arecoline.

Two adverse birth outcomes were observed in the six exposed newborns (table 1). In both cases, risk factors other than chronic betel quid consumption could be excluded from maternal records, and neonatal brain ultrasonography was inconclusive. Focal inflammatory changes in the amniochorial membranes were observed in the placentas in both cases (table 1), and in case 3 a decreased median diameter of the vessels in both maternal and fetal surface villi was also observed

Although the effects of betel chewing are well established in adults, teratogenic effects of prenatal betel exposure have only been shown in animal models, ${ }^{5}$ and data for humans are scant. $^{2}$

In our study, arecoline was determined in biological matrices accounting for acute and chronic fetal exposure to this substance, exposure associated with placental abnormalities, and neonatal outcomes, including neonatal withdrawal syndrome, as an exceptional adverse birth outcome not yet described in the literature. The recognised biochemical effects of arecoline on the autonomic nervous system and the recognised embryotoxicity in animals, together with our findings, allowed us to hypothesise a number of effects on the fetus related to abnormalities of the fetoplacental circulation, similar to those observed with nicotine or cocaine.

These preliminary findings did not allow any definitive conclusion on the correlation between fetal exposure to arecoline and clinical outcomes. Information on differences in patterns of drug use (amount, timing, and duration of drug exposure), related to clinical outcomes, was not

Table 1 Results of the clinical observational study on six newborns from mothers who chewed betel nut during pregnancy

\begin{tabular}{|c|c|c|c|c|c|c|c|c|}
\hline \multirow[b]{2}{*}{$\begin{array}{l}\text { Case } \\
\text { No }\end{array}$} & \multicolumn{4}{|c|}{ Somatometry } & \multirow[b]{2}{*}{ Clinical signs } & \multirow[b]{2}{*}{ Placental morphology } & \multicolumn{2}{|c|}{$\begin{array}{l}\text { Arecoline in biological } \\
\text { matrices }(\mu \mathrm{g} / \mathrm{g})\end{array}$} \\
\hline & $\begin{array}{l}\text { Birth } \\
\text { weight } \\
\text { (g) }\end{array}$ & $\begin{array}{l}\text { Crown-heel } \\
\text { height }(\mathrm{cm})\end{array}$ & $\begin{array}{l}\text { Cranial } \\
\text { perimeter } \\
(\mathrm{cm})\end{array}$ & $\begin{array}{l}\text { Gestation } \\
\text { (weeks) }\end{array}$ & & & Meconium & Placenta \\
\hline 1 & 3450 & 51 & 34 & 41 & None & $577 \mathrm{~g}$; macro and micro normal & 0.008 & ND \\
\hline 2 & 3090 & 49 & 34 & 38 & $\begin{array}{l}\text { Neonatal withdrawal } \\
\text { syndrome treated with } \\
5 \mathrm{mg} / \mathrm{kg} \text { phenobarbital } \\
\text { for } 3 \text { subsequent days }\end{array}$ & $\begin{array}{l}655 \mathrm{~g} \text {; macro normal; } \\
\text { micro acute } \\
\text { focal chorioamnionitis }\end{array}$ & NA & 0.012 \\
\hline 3 & 2430 & 47 & 33 & 41 & $\begin{array}{l}\text { Low birth weight, low } \\
\text { intrauterine growth, } \\
\text { small for gestational } \\
\text { age, hyporeflexia, hypotonia }\end{array}$ & $\begin{array}{l}435 \mathrm{~g} \text {; macro normal; } \\
\text { micro acute focal } \\
\text { chorioamnionitis, reduced } \\
\text { vascular diameter }\end{array}$ & 0.006 & 0.009 \\
\hline 4 & 3260 & 49 & 34 & 39.6 & None & $548 \mathrm{~g}$; macro and micro normal & 0.022 & 0.013 \\
\hline 5 & 2865 & 48 & 32 & 38.3 & None & $498 \mathrm{~g}$; macro and micro normal & NA & 0.015 \\
\hline 6 & 3575 & 52 & 35 & 40.4 & None & $468 \mathrm{~g}$; macro and micro normal & 0.017 & 0.014 \\
\hline
\end{tabular}

NA, Not available; ND, not detected. 
available from the study questionnaire, nor could it be deduced from the arecoline concentration in the meconium, as is the case for other illicit drugs. Furthermore, as this was the first time that arecoline had been detected in meconium and placenta, no concentration ranges were available, which may have allowed speculations on amounts.

Our observations require support from further investigations, addressing the above issues and including an extended follow up of prenatally exposed newborns in areas with a high prevalence of betel nut consumption.

\section{Authors' affiliations}

O García-Algar, O Vall, C Puig, Paediatric Service, Unitat de Recerca

Infància i Entorn (URIE), Hospital del Mar, Barcelona, Spain and Departament de Pediatria, Ginecologia i Obstetricia, i Medicina Preventiva, Universitat Autònoma, Barcelona, Spain

F Alameda, Pathology Service, Hospital del Mar

M Pellegrini, R Pacifici, S Pichini, Drug Research and Evaluation Department, Istituto Superiore di Sanità, Rome, Italy

This study was supported by "Area Progetto Droga" (Convenzione $513 \mathrm{~A} / 4$ ) from Istituto Superiore di Sanità, Roma, Italy.
Competing interests: none declared

Correspondence to: Dr García-Algar, Pediatric Service, Hospital del Mar, Paseo Marítimo 25-29, 08003 Barcelona, Spain;

OGarciaA@imas.imim.es

Accepted 13 October 2004

\section{REFERENCES}

1 Gupta PC, Warnakulasuriya S. Global epidemiology of areca nut usage. Addict Biol 2002;7:77-83.

2 Yang MS, Chung TC, Yang MJ, et al. Betel quid chewing and risk of adverse birth outcomes among aborigines in eastern Taiwan. $J$ Toxicol Environ Health A $2001 ; 64: 465-72$

3 Pichini S, Pellegrini M, Pacifici R, et al. Quantification of arecoline (Arena Nut alcaloid) in neonatal biological matrices by high-performance liquid chromatography/electrospray quadrupole mass spectrometry. Rapid Commun Mass Spectrom 2003;17:1958-64.

4 Langston C, Kaplan C, Macpherson T, et al. Practice guideline for examination of the placenta: developed by the Placental Pathology Practice Guideline Development Task Force of the College of American Pathologists. Arch Pathol Lab Med 1997;121:449-76.

5 Sinha A, Rao AR. Embryotoxicity of betel nuts in mice. Toxicology 2001;37:315-26.

\section{bmjupdates+}

bmjupdates+ is a unique and free alerting service, designed to keep you up to date with the medical literature that is truly important to your practice.

bmjupdates+ will alert you to important new research and will provide you with the best new evidence concerning important advances in health care, tailored to your medical interests and time demands.

\section{Where does the information come from?}

bmjupdates+ applies an expert critical appraisal filter to over 100 top medical journals A panel of over 2000 physicians find the few 'must read' studies for each area of clinical interest

Sign up to receive your tailored email alerts, searching access and more...

www.bmjupdates.com 